\title{
Lentivirus-like particles in connective tissue tumours of fish from German coastal waters
}

\author{
Kerstin Anders ${ }^{1}$, Ingrid Hilger ${ }^{2}$, Heino Möller ${ }^{1}$ \\ ${ }^{1}$ Institut für Meereskunde an der Universität, Düsternbrooker Weg 20, w-2300 Kiel 1, Germany \\ ${ }^{2}$ Universitätsklinikum Göttingen, Zentrum Innere Medizin, Abt. Klinische Biochemie, Robert-Koch-Str. 40, W-3400 Göttingen, Germany
}

\begin{abstract}
A conspicuous yellow tumour was found for the first time in January 1989 among hooknose Agonus cataphractus collected from different parts of the German Wadden Sea. Prevalence of the tumour was $0.7 \%$. The tumours arose from connective tissue and were classified as fibromas or possibly fibrosarcomas. Electron microscopy revealed the presence of lentivirus-like particles within cytoplasmic vacuoles of tumour cells. This is the first report of a lentivirus in a lower vertebrate or from an animal residing in the aquatic environment.
\end{abstract}

Since the first large-scale surveys of marine fish for diseases in 1968 in Californian waters (Cooper \& Keller 1969) and 1970 in the Irish Sea (Perkins et al, 1972), concern has been expressed that the health of wild fish might be affected by anthropogenic wastes disposed into coastal waters. As a result, many additional surveys have been conducted, mainly covering coastal waters of North America and western Europe (Mix 1986, Möller \& Anders 1986).

Those studies conducted in the North Sea area, where intergovernmental approaches to monitor pollution effects include disease surveys, have focussed particularly on flatfish. One of the more recent surveys in 1988-89 covered the German Wadden Sea, the shallow, sandy-muddy coastal zone between the borders to Denmark in the north and The Netherlands in the west (Möller \& Anders in press). That survey, and a pilot study in the neighbouring Elbe estuary from 1981 to 1986, revealed a number of 'new' fish diseases, such as the food-induced buccal granulomatosis of smelt Osmerus eperlanus (Anders \& Möller 1987), spawning papillomatosis of smelt which is linked with a herpesvirus infection (Anders 1989b), and 'yellow pest' of cod
Gadus morhua, probably induced by a CytophagaFlexibacter-like bacterium (Hilger et al. 1991).

During the Wadden Sea survey, tumours were reported from hooknose Agonus cataphractus for the first time. This bottom-fish species is distributed from the White Sea to northern France, and from Iceland to the western Baltic. In the Wadden Sea, it is one of the most abundant by-catch species in the local trawl fishery for brown shrimp Crangon crangon. The population biology of the hooknose is largely unknown, but young stages of about $2 \mathrm{~cm}$ total body length occur in catches from May onward. Adults rarely grow larger than $17 \mathrm{~cm}$ in the Wadden Sea, where they mainly feed on brown shrimp.

Among 1653 fish examined, 11 tumour-carrying individuals were found. In 6 fish, tumours of a distinct yellow colour were found. In other fish, the tumours were skin-coloured (black to reddish). Two specimens each had 1 tumour of both types (Fig. 1). The first tumour of this kind was found in January 1989 and was not observed the previous year. Independently, local fishermen reported seeing the yellow tumour type for the first time in April 1990, after having caught several conspicuously affected fish with tumours on their heads in the Wadden Sea near the isle of Amrum.

The 7 tumours histologically studied ranged from 3 to $9 \mathrm{~mm}$ in diameter and represented both globular and flat forms. Based on histological evaluation, 6 of the tumours were preliminarily classified as benign and arising from connective tissue, thus representing fibromas. In one case, a tendency of tumour cells to invade muscular tissue was observed. Based on histological characteristics, the tumours could be grouped 


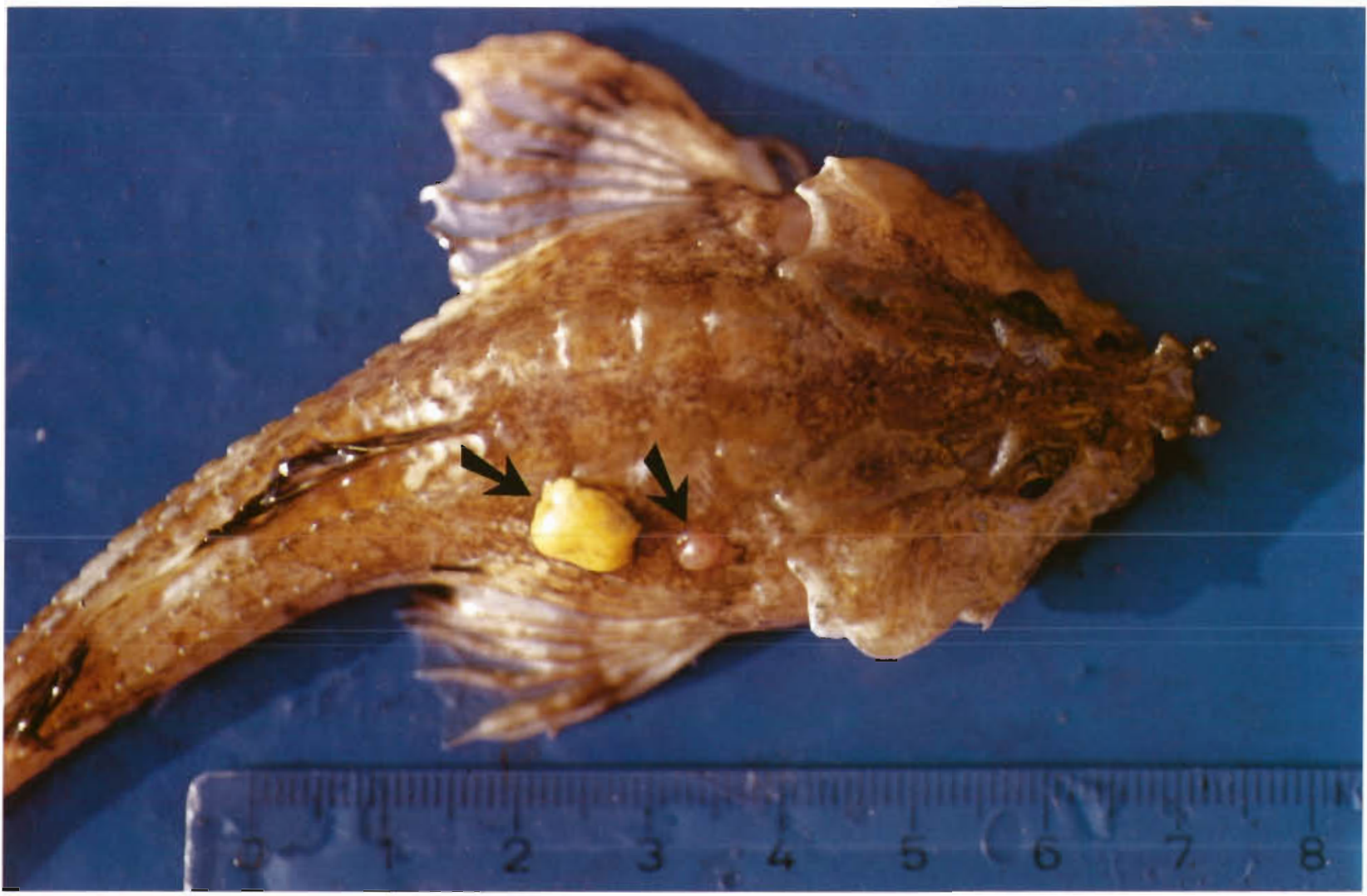

Fig. 1. Agonus cataphractus. A hooknose from the German Wadden Sea, bearing 2 conspicuous tumours (arrows) on the body surface. Scale shown is in $\mathrm{cm}$

into 2 types corresponding to their colour. Skin-coloured tumours displayed slightly proliferated epidermal layers, an intact basal lamina, strong proliferation of connective tissue cells which were well interlaced with bundles of collagen, and a more or less strong vascularization of the tumour tissue. The 2 yellow tumours examined differed from the others in that they had additionally a high abundance of immune cells (e.g. lymphocytes and granulocytes), as well as several multi-nucleated giant cells, within the proliferative tissue.

Thin sections of tumour tissue examined using electron microscopy showed lentivirus-like particles in all 7 tumours studied (Fig. 2). The particles were numerous in the yellow-type tumours, but occurred infrequently in the skin-coloured tumours. Affected cells were characterized by a dense endoplasmatic reticulum, different kinds of cytoplasmic vesicles, numerous cytoplasmic vacuoles, crystalline substructures, and enlarged mitochondria. The identity of these particleharbouring cells was not determined, nor was nontumour tissue examined. However, the morphology of affected cells resembled that of lymphocytes.

The virus-like particles occurred within cytoplasmic vacuoles, were of spherical shape, and measured $99 \mathrm{~nm}$ in diameter on average $(n=25$, range $=86$ to $132 \mathrm{~nm}$ ). They exhibited several morphological similarities to known lentiviruses, e.g. with respect to occurrence in cytoplasmic vacuoles, diameter, lipid envelope, occasional double cores, and evidence for lateral bodies. Particles with cone-shaped cores, typical of the lentivirus human immunodeficiency virus (HIV) (Gelderblom et al. 1987), were rarely observed. They were outnumbered by particles exhibiting tubular cores, which are also common in other lentiviruses.

Attempts to replicate the virus-like particles in fish cell cultures and experimental transmission studies have not been carried out so far. Members of the lentivirus subfamily characterized to date are exogenous retroviruses of warm-blooded vertebrate hosts, such as sheep, goats, cows, horses, cats, and primates (including man), which induce a number of different diseases (Letvin 1990). Our finding represents the first observation of lentivirus-like particles in tissues of a cold-blooded animal. So far, all retroviruses known to infect lower vertebrates, especially fish, belong to the subfamily Oncovirinae (C-type) (Dahlberg 1988). For some of these viruses, oncogenicity has been demon- 
strated (Anders \& Yoshimizu unpubl. data). It remains unclear whether the possible lentivirus of hooknose is directly related to tumour induction or whether it occurs accidentally within the tumour tissue due to the presence of infected immune cells. Lentiviruses so far have not been observed in tumour tissue.

Fish virology has attracted wider scientific attention with the development of the aquaculture industry. Today, viral diseases like VHS (viral haemorrhagic septicaemia), IPN (infectious pancreatic necrosis) or IHN (infectious hematopoietic necrosis) are limiting factors in many areas, particularly in salmonid culture
(Roberts 1982). Outside of fish ponds and cages, evidence is accumulating that viruses play an important role in the aquatic environment (Bergh et al. 1989), as well as being disease agents for aquatic organisms.

Among populations of wild fish, ulcer disease in Danish cod (Jensen et al. 1979), an ulcer disease recently spreading among southeast Asian freshwater fish stocks (Frerichs et al. 1986), and 'spinning disease' of several fish species along the American Atlantic coast (McAllister et al. 1984) have been associated with viral infections, although the causative agents so far have not been identified with certainty. On the other

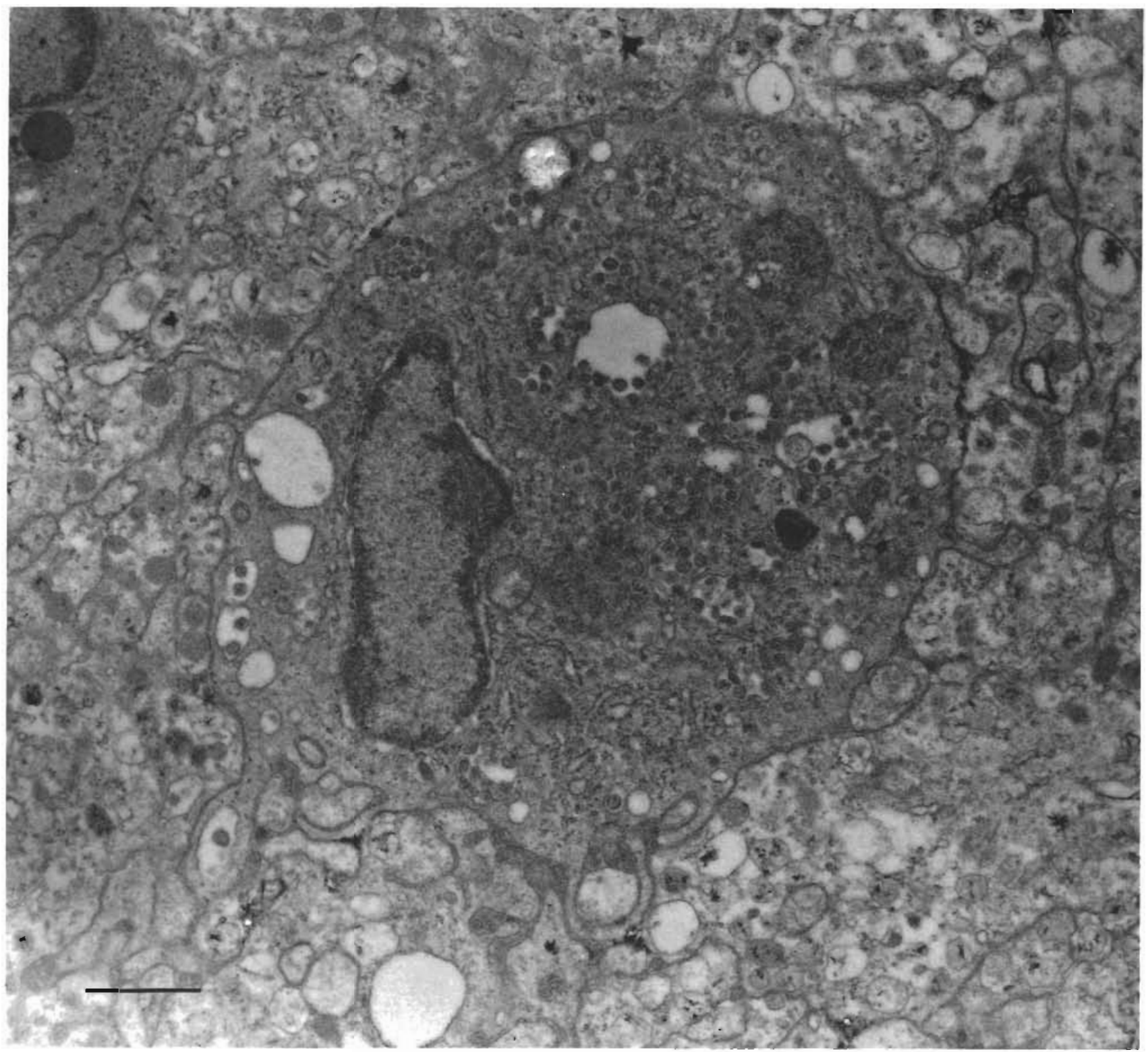

Fig. 2. Agonus cataphractus. Numerous lentivirus-like particles in cytoplasmic vacuoles of a possible lymphocyte within tumour tissue of hooknose. Scale bar = $1 \mu \mathrm{m}$ 
hand, the viral etiology of lymphocystis disease (Anders 1989a) and VEN (viral erythrocytic necrosis) (Smail 1982) in wild fish is well known.

Fish skin tumours associated with members of 6 virus families have been found (Anders \& Yoshimizu unpubl. data). Only in the case of 3 closely related herpesviruses has the viral etiology been proved by fulfilling River's postulates (Kimura et al. 1981, Sano et al. 1983, 1985, Yoshimizu et al. 1987). However, the regular observation of viruses within cells of several tumour types suggests that further research efforts will detect additional occurrences.

The recent discovery of the hooknose tumour and associated virus-like particles is remarkable, since it is the first observation of lentivirus-like particles from lower vertebrates as well as from tumour tissue. The significance of this finding is not clear, and further research is needed. The virus-cell relationship, infectivity, the role of the viral particles in tumour induction, and the usefulness of this system as an animal model in AIDS research remain to be clarified. Furthermore, the lentiviral nature of the particles has to be confirmed by molecular-genetic techniques.

Acknowledgements. This study is part of a survey financed by the German Federal Environmental Agency and the Governments of Schleswig-Holstein and Niedersachsen in Germany.

\section{LITERATURE CITED}

Anders, K. (1989a). Lymphocystis disease of fishes. In: Ahne, W., Kurstak, E. (eds.) Viruses of lower vertebrates. Springer, Heidelberg, p. 141-160

Anders, K. (1989b). A herpesvirus associated with an epizootic epidermal papillomatosis in European smelt (Osmerus eperlanus). In: Ahne, W., Kurstak, E. (eds.) Viruses of lower vertebrates. Springer, Heidelberg, p. 184-197

Anders, K., Möller, H. (1987). Food-induced granulomatosis in European smelt, Osmerus eperlanus. Can. J. Fish. Aquat. Sci. 44: 1848-1854

Bergh, Ø., Børsheim, K. Y., Bratbak, G., Heldal, M. (1989). High abundance of viruses found in aquatic environments. Nature, Lond. 340: 467-468

Cooper, R. C., Keller, C. A. (1969). Epizootiology of papillomas

Responsible Subject Editor: W. Ahne, Munich, Germany in English sole, Parophrys vetulus. Natl Cancer Inst. Monogr. 31. 173-185

Dahlberg, J. E. (1988). An overview of retrovirus replication and classification. Adv vet. Sci. comp. Med. 32: 1-35

Frerichs, G. N., Millar, S. D., Roberts, R. J. (1986). Ulcerative rhabdovirus in fish in South-East Asia. Nature, Lond. 322: 216

Gelderblom, H. R., Hausmann, E. H. S., Özel, M., Pauli, G., Koch, M. A. (1987). Fine structure of human immunodeficiency virus (HIV) and immunolocalization of structural proteins. Virology 156: 171-176

Hilger, I, Ullrich, S., Anders, K. (1991). A new ulcerative flexibacteriosis-like disease ('yellow pest') affecting young Atlantic cod Gadus morhua from the German Wadden Sea. Dis. aquat. Org. 11: 19-29

Jensen, N. J., Bloch, B., Larsen, J. L. (1979). The ulcussyndrome in cod (Gadus morhua). III. A preliminary virological report. Nord. Veterinaermed. 31, 436-442

Kimura, T., Yoshimizu, M., Tanaka, M. (1981). Studies on a new virus (OMV) from Oncorhynchus masou. II. Oncogenic nature. Fish Path. 15: 149-153

Letvin, N. L. (1990). Animal models for AIDS. Immunology Today 11: 322-326

McAllister, P. E., Newman, M. W., Sauber, J. H., Owens, W. J. (1984). Isolation of infectious pancreatic necrosis virus (serotype $\mathrm{Ab}$ ) from diverse species of estuarine fish. Helgoländer Meeresunters. 37: 317-328

Mix, M. C. (1986). Cancerous diseases in aquatic animals and their association with environmental pollutants: a critical literature review. Mar. environ. Res. 20: 1-141

Möller, H., Anders, K. (1986). Diseases and parasites of marine fishes. Möller, Kiel

Möller, H., Anders, K. (in press). Epidemiology of fish diseases in the Wadden Sea. ICES J. mar. Sci.

Perkins, E. J., Gilchrist, J. R., Abbott, O. J. (1972). Incidence of epidermal lesions in fish of the north-east Irish Sea area, 1971. Nature, Lond. 238: 101-103

Roberts, R. J. (ed.) (1982). Microbial diseases of fish. Academic Press, London

Sano, T., Fukuda, H., Furukawa, M. (1985). Herpesvirus cyprini: biological and oncogenic properties. Fish Path. 20: 381-388

Sano, T., Fukuda, H., Okamoto, N., Kaneko, F. (1983). Yamame tumor virus: lethality and oncogenicity. Bull. Jap. Soc. scient. Fish. 49: 1159-1163

Smail, D. A. (1982). Viral erythrocytic necrosis in fish: a review. Proc. R. Soc. Edinb. 81B: 169-176

Yoshimizu, M., Tanaka, M., Kimura, T. (1987). Oncorhynchus masou virus (OMV): incidence of tumor development among experimentally infected representative salmonid species. Fish Path. 22: 7-10

Manuscript first received: January 1, 1991

Revised version accepted: May 24, 1991 